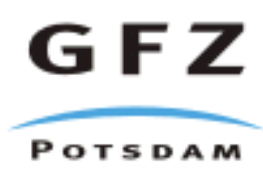

Originally published as:

Mangili, C., Brauer, A., Plessen, B., Moscariello, A.(2007): Centennial-scale oscillations in oxygen and carbon isotopes of endogenic calcite from a 15,500 varve year record of the Piànico interglacial. - Quaternary Science Reviews, 26, 13-14, 1725-1735,

DOI: 10.1016/j.quascirev.2007.04.012 


\title{
Centennial-scale oscillations in oxygen and carbon isotopes of endogenic calcite from a 15,500 varve year record of the Piànico interglacial
}

\author{
Clara Mangili $^{\mathrm{a}}{ }^{*}$, Achim Brauer $^{\mathrm{a}}$, Birgit Plessen $^{\mathrm{a}}$, Andrea Moscariello $^{\mathrm{b}}$ \\ ${ }^{a}$ GeoForschungsZentrum (GFZ), Section 3.3-Klimadynamik und Sedimente, Telegrafenberg, D-14473 \\ Potsdam, Germany \\ ${ }^{b}$ Cambridge Quaternary, Department of Geography, University of Cambridge, Downing Street, Cambridge CB2 \\ $3 E N, U K$
}

\begin{abstract}
The palaeolake record from Piànico (Southern Alps) comprises a sequence of 15,500 continuous calcite varves formed during peak interglacial conditions around $400 \mathrm{ka}$ ago. The varved nature of these deposits allows precise sub-sampling of five varve year intervals for stable isotope analyses. All samples consist of calcite precipitated in the epilimnion of the lake, with contents of detrital carbonate below $4 \%$. Four significant negative $\delta^{18} \mathrm{O}$ oscillations occurred during the upper half of the interglacial. The most prominent of these oscillations has an amplitude of $-1.1 \%$ and lasted 780 varve years. The three other oscillations are shorter (125-195 varve years) and of lower amplitude (0.4-0.9\%o). An additional major drop in $\delta^{18} \mathrm{O}$ occurs 315 varve years before the end of continuous calcite precipitation in the lake. This shift marks the end of long interglacial conditions and the beginning of harsher climate conditions and glacier advances in the Southern Alps. In contrast, the four $\delta^{18} \mathrm{O}$ oscillations within the period of continuous formation of calcite varves reflect natural intra-interglacial climate dynamics.
\end{abstract}

\section{Introduction}

Stable isotope analysis of calcite precipitated within the annual cycle in the epilimnion of lakes $\left(\delta^{18} \mathrm{O}_{\text {carb }}\right)$ is a valuable tool for reconstructing climatic changes, provided that samples are not contaminated with allochthonous detrital carbonates. Previous works mainly focussed on Holocene and Lateglacial sediment records from present lakes (e.g. Siegenthaler et al., 1984; Siegenthaler and Eicher, 1986; McKenzie and Hollander, 1993; Kuc et al., 1998; Leng et al., 1999; Schwander et al., 2000; von Grafenstein et al., 2000; Hilfinger IV et al., 2001; 
Teranes and McKenzie, 2001; Kirby et al., 2002). Although these studies have demonstrated the great potential of $\delta^{18} \mathrm{O}_{\text {carb }}$ as climate proxy, comparable data from palaeolakes from previous interglacials are still rare (e.g. Binka and Nitychoruk, 1995; Drescher-Schneider and Papesch, 1998; Boettger et al., 2000; Nitychoruk, 2000; Nitychoruk et al., 2005). In particular, surprisingly little is known about terrestrial isotope records correlating with Marine Isotope Stage (MIS) 11, although this interglacial is considered a good analogue to the Holocene, with respect to orbital forcing (e.g. Berger and Loutre, 2002; Loutre, 2003). Many efforts have been undertaken to study long marine records (e.g. McManus et al., 1999) and Antarctic ice cores (Petit et al., 1999; EPICA community members, 2004) that demonstrated a 27-30 ka interglacial around $400 \mathrm{ka}$ ago, including a period of $18 \mathrm{ka}$ of full or peak interglacial conditions (de Abreu et al., 2005). The only available stable isotope record from a lacustrine record of this period is from Ossówka, in Eastern Poland (Nitychoruk, 2000; Nitychoruk et al., 2005). The sediment record from the Piànico palaeolake provides complementary data for the Southern Alps at sub-decadal resolution, allowing the study of natural climate variability during peak interglacial conditions at $400 \mathrm{ka}$ ago, a period for which any kind of human interference can be excluded.

\section{Study site and sediments}

Deposits of the Piànico palaeolake outcrop at an altitude between 280 and $350 \mathrm{~m}$ a.s.1. in the Borlezza Valley $\left(45^{\circ} 48^{\prime} \mathrm{N}, 10^{\circ} 2^{\prime} \mathrm{E}\right.$; Fig. 1), a northwestern tributary to recent Lake Iseo, Southern Alps. The Piànico palaeolake is ca $3 \mathrm{~km}$ long and 500-800m wide (Casati, 1968). The presence of varves indicates meromictic deep water conditions. The catchment of the palaeolake forming the lower part of the Borlezza Valley (Fig. 2) is constituted mainly by Upper Triassic dolomitic rocks (Dolomia Principale), and subordinately by limestones belonging to the Calcare di Zorzino Unit (Provincia di Bergamo, 2000).

The $48 \mathrm{~m}$ thick sequence of lacustrine sediments of the Piànico Formation (Moscariello et al., 2000) is subdivided into four units of partly finely laminated sediments: in this paper, only the upper two units labelled as BVC (Banco Varvato Carbonatico; Fig. 3) and MLP (Membro di La Palazzina; Fig. 3) are considered. These units are exposed in several outcrops which have been microscopically correlated on a varve-to-varve basis (Mangili et al., 2005; Brauer et al., 2007a). A composite lithological log was established through the stratigraphic combination of three outcrops: Main Section, Wall Section and Deer Section (Figs 2 and 3; Brauer et al., 2007a). 


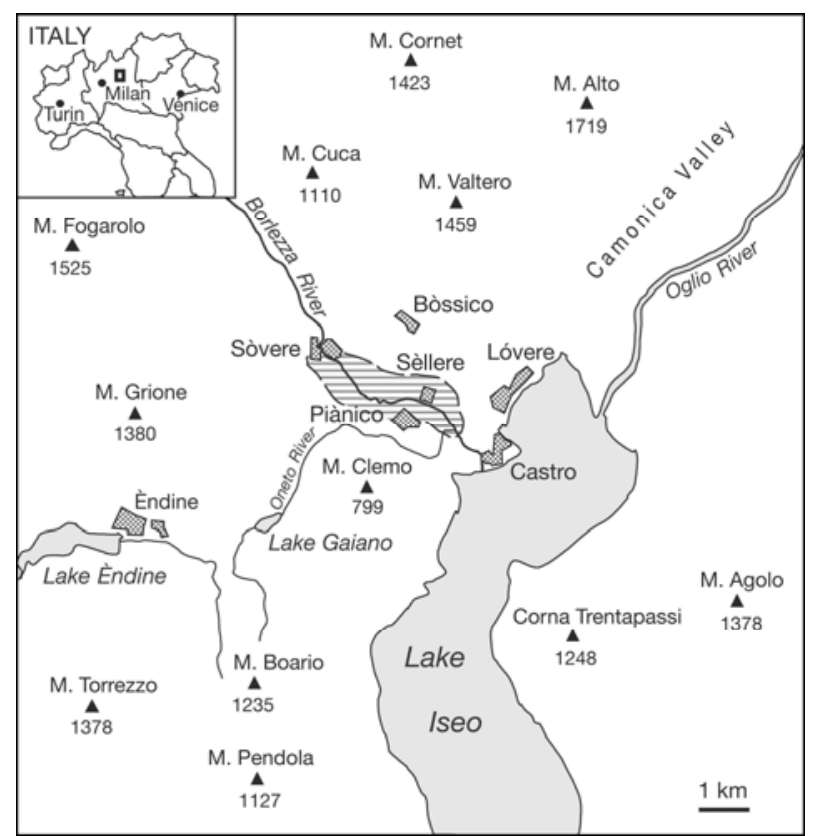

Fig. 1. Location of the Piànico-Sèllere Basin and reconstructed extension of the palaeolake (dashed area; modified after Casati, 1968).

The BVC unit represents a long period of 15,500 years of interglacial climate, as revealed by the continuous formation of calcite varves and by vegetation reconstructions (e.g. Amsler, 1900; Maffei, 1924; Moscariello et al., 2000; Rossi, 2003). The varves of this unit (Fig. 4) are composed of two laminae: a spring-summer light lamina formed by biochemically precipitated calcite with crystal sizes of $2-15 \mu \mathrm{m}$, and an autumn-winter dark lamina composed of organic matter, diatom frustules and few scattered detrital grains (Moscariello et al., 2000; Brauer et al., 2007a). Summer layers (Fig. 4b) consist up to 98\% of calcite and constitute $69-98 \%$ of the total varve thickness. Intercalated detrital layers (Fig. 4a) reflect surface runoff episodes caused by extreme precipitation events (Mangili et al., 2005).

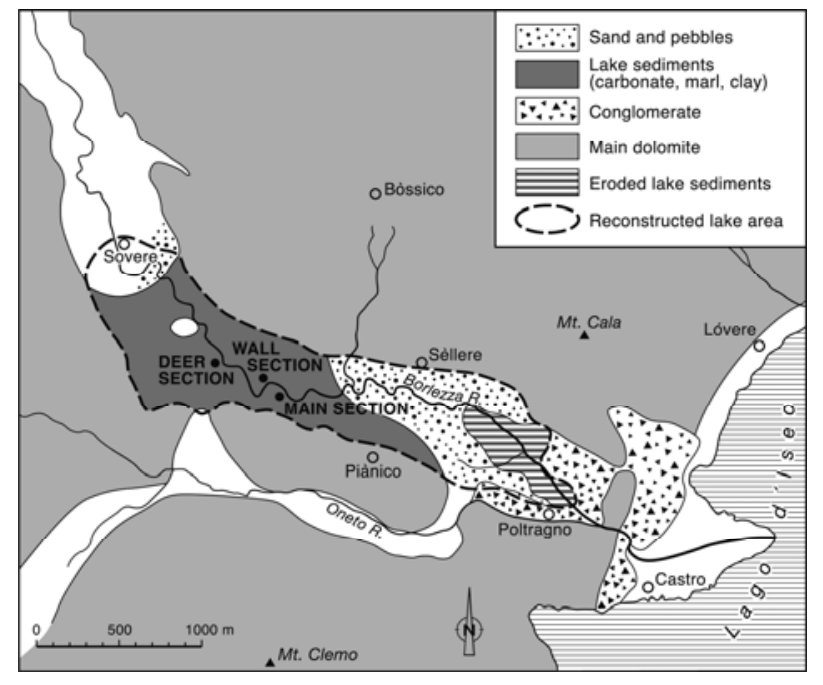

Fig. 2. Distribution of the Pleistocene sediments in the basin of the Piànico palaeolake during the early stages of lacustrine sedimentation (modified after Casati, 1968). The sampled outcrops are indicated (Main Section, Wall Section and Deer Section). 
The MLP unit exhibits a succession of six intervals of detrital sediments (16-205.5 cm thick; D1-D6 in Fig. 3) intercalated by five intervals of predominantly endogenic calcite sediments (10-185.5 cm thick; C1-C5 in Fig. 3). Thickness of both detrital and endogenic dominated sediment sections generally decreases towards the top of the profile. Calcite varves similar to the varves of the BVC unit only formed in the lowermost section of endogenic calcite $(\mathrm{C} 1$ in Fig. 3). The lithological variations of predominantly autochthonous and allochthonous sediment deposition correlate well with vegetation changes (Moscariello et al., 2000; Rossi, 2003), both indicating millennial-scale climatic oscillations.

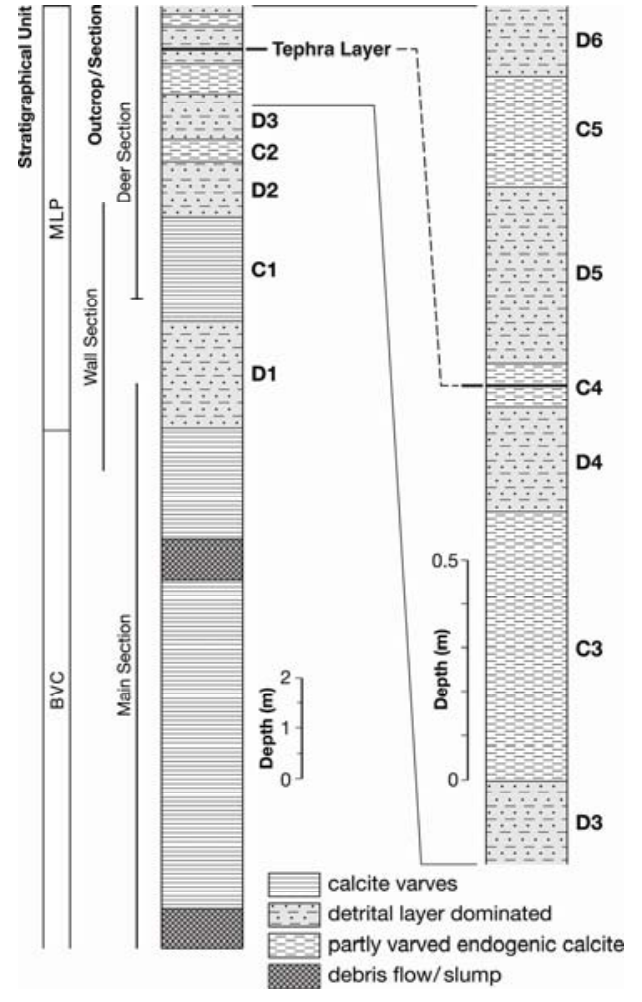

\section{Methods}

\subsection{Field sampling}

A composite stratigraphic profile was established for the studied interval in order to avoid sampling disturbed by local slump deposits. The BVC unit was sampled for isotope analyses in the Main and Wall Sections; the MLP unit was sampled in the Wall and Deer Sections (Fig. 2).

After cleaning the outcrop with a sharp knife to obtain a smooth and vertical surface, sediment blocks of $33 \times 5 \mathrm{~cm}$ were carved out from the sediments with $5 \mathrm{~cm}$ overlap each. 
The sample boxes of stainless steel have removable side walls in order to extract the sediment blocks in the laboratory without breakage. After drying at room temperature, the sample blocks were covered with a transparent epoxy resin (Araldite ${ }^{\circledR} 2020$ ) for further fixation. The epoxy impregnated up to ca 1-2 $\mathrm{mm}$ from the surface of the sediment blocks. The sample blocks then were sufficiently stable to be cut into three parallel ca $2 \mathrm{~cm}$ thick slices, one of which was used for thin sectioning and another for isotope sub-sampling.

\subsection{Sub-sampling for isotope analyses}

Isotope sub-samples were selected on the basis of lithological data from thin section inspection. This enabled both the selection of sample intervals comprising precisely five varves (Fig. 4) and the assurance that these samples contain at least $96 \%$ of endogenic calcite, in order to exclude a bias through contamination with detrital carbonates. A $<4 \%$ detrital contamination is within the range of analytical error (Mangili et al., in prep.).
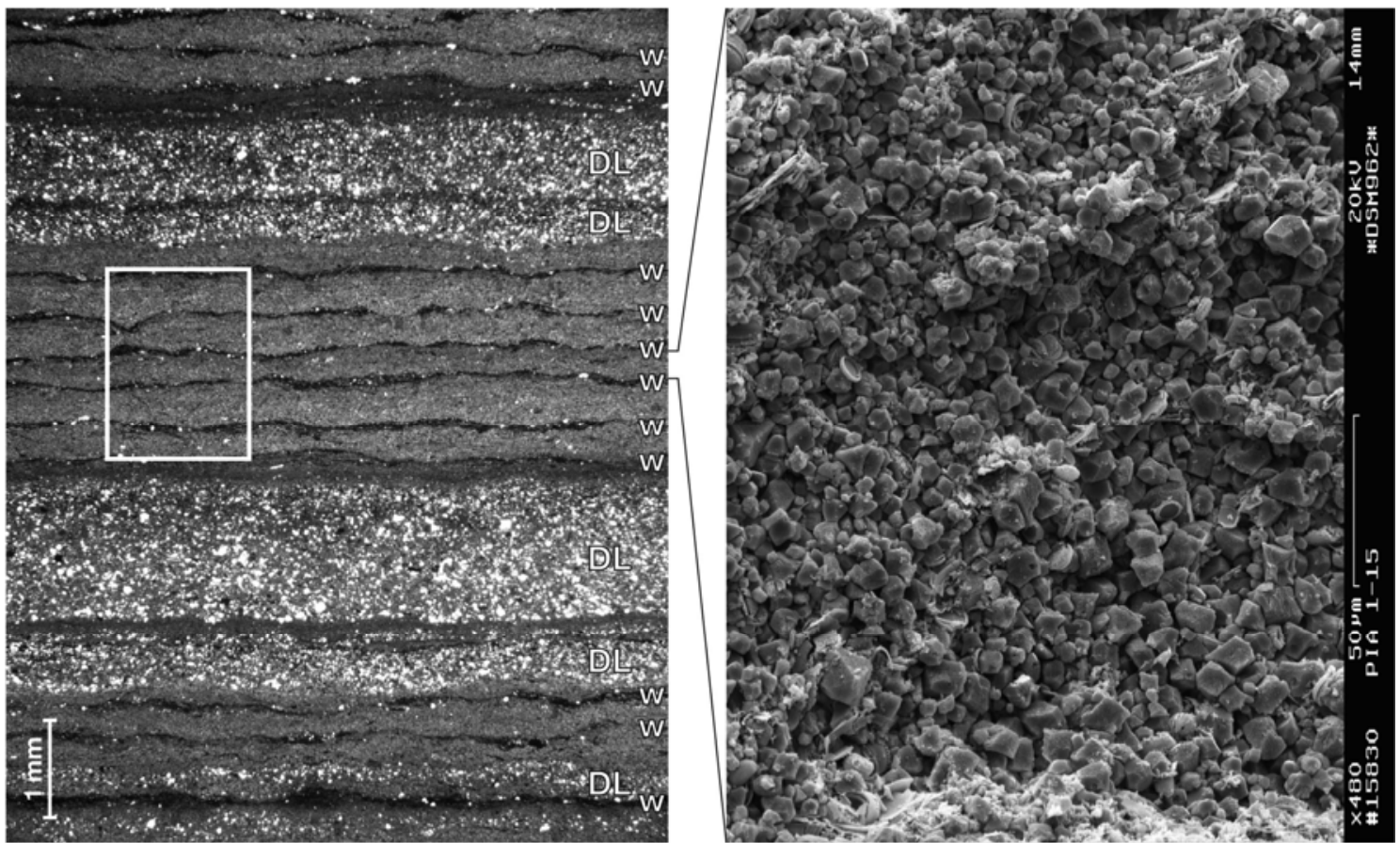

Fig. 4. Thin section image of varves and detrital layers (crossed polarised light; left). Winter layers (w) and detrital layers (DL) are indicated. The rectangle marks a typical sample interval for isotope analyses of five varves excluding detrital layers. S.E.M. picture (right) showing that summer layers are composed of pure endogenic calcite crystals of different sizes.

In total, 387 samples were carefully scratched from fresh cut surfaces of the sediment blocks with a sharp scalpel. From all samples, 14 were obtained from two of the non-varved intervals in the MLP unit (C2 and $\mathrm{C} 3$ in Fig. 3) preventing from precise time control. Thickness of 
these samples was in the same range $(2-4 \mathrm{~mm})$ as in the varved part. No samples were taken in the detrital intervals of the MLP, because high amounts of detrital carbonates prevented the selection of endogenic calcite samples.

The time intervals between subsequent samples varied, in the upper 9350 varve years of the BVC, between 0 (continuous samples) and 100 varve years. The lower part of the BVC (ca 6150 varve years) was sampled at lower resolution between ca 10 and 700 varve years. Sample resolution in the MLP varied between 0.5 and $20 \mathrm{~cm}$.

\subsection{Isotope analyses}

The stable isotope composition of the sediments was analysed at GFZ Potsdam in continuous flow mode with a Finnigan GasBench II connected with a DELTAplusXL mass spectrometer. From each sample, ca $0.25 \mathrm{mg}$ were loaded into $10 \mathrm{ml}$ Labco Exetainers vials. Two subsamples were analysed for each sample. After automatically flushing with He, the isotope samples were reacted in phosphoric acid $(100 \%$, density 1.93$)$ at $75^{\circ} \mathrm{C}$ for $60 \mathrm{~min}$ in a Finnigan GasBench preparation system, following the analytical procedure described in Spötl and Vennemann (2003). Isotope compositions of the sediments were given relative to the VPDB standard in the conventional d-notation, and were calibrated against three international reference standards (NBS 19, CO1, CO8). The standard deviation (1 sigma) for both standard and duplicate analyses was $0.06 \%$ for $\delta^{13} \mathrm{C}$ and $0.08 \%$ for $\delta^{18} \mathrm{O}$.

\section{Chronology}

A floating chronology has been established for the studied interval based on varve counting in the BVC unit with well-preserved varves, and sedimentation rate estimates in the MLP unit with only few varved intervals.

The chronology for the upper 9350 years of the BVC is based on varve counting in thin sections, using a petrographic microscope. Due to the exceptional preservation of varves, the error estimate of varve counting for this interval amounts to no more than $1-2 \%$. For the lower part of the BVC, a preliminary chronology (ca 6150 varve years) has been established through varve counting with a 10-times magnification lens in the outcrop. The counting error in this part of the chronology is slightly higher (ca 5\%) due to the less precise counting technique. 
The duration of the studied part of the MLP unit has been determined to ca 8500 years, based on a combination of varve counting and calculation of sedimentation rates using micro-facies data (Brauer et al., 2007a). This is considered as a minimum estimate because of the high possibility of erosion caused by numerous thick detrital layers intercalated within this interval. The floating chronology has been anchored to an absolute time scale by means of tephrochronology. A $0.7 \mathrm{~mm}$ thick volcanic ash layer has been geochemically and mineralogically correlated with the Roccamonfina Brown Leucitic Tuff (Brauer et al., 2007b) dated from near-vent deposits at $393 \pm 12 \mathrm{ka}$. Using the estimated length of the MLP (8500 years) and the varve count from the BVC unit (15,500 years), the studied interval comprised the time span between about $415.1 \pm 12 \mathrm{ka}$ (bottom of the BVC unit) and 391.1 $\pm 12 \mathrm{ka}$ (top of the studied sequence), with the BVC/MLP boundary at $399.6 \pm 12 \mathrm{ka}$.

\section{Results}

The $\delta^{18} \mathrm{O}$ values of endogenic calcite in the studied interval of the Piànico record range between $-10.1 \%$ and $-8 \%$ (Fig. 5(a) and 6(a)). Both the lightest and the heaviest $\delta^{18} \mathrm{O}$ values occur in the BVC unit. $\delta^{18} \mathrm{O}$ values of three endogenic calcite intervals of the MLP unit (C1C3, Fig. 5(a) and Table 1) fall in the range $-8.3 \% \%$ to $-9.2 \%$. The smaller amplitude in these sections might be a consequence of the small number of samples from this interval $(n=41)$.

The general structure of the $\delta^{18} \mathrm{O}$ curve from the peak interglacial (BVC unit) is tripartite (Fig. 5 and Table 1): from 1779 to $1415 \mathrm{~cm}$ (ca 5750 varve years) $\delta^{18} \mathrm{O}$ gradually rises, from 9.2\%oto $-8.3 \%$. Short-term oscillations might not be detected in this part of the record due to the low sampling resolution. From 1415 to $1173 \mathrm{~cm}$ depth, $\delta^{18} \mathrm{O}$ values remain relatively stable except two short-term oscillations of 165 and 195 varve years. Despite these lighter oscillations, the mean $\delta^{18} \mathrm{O}$ value in this ca 4350 year long period reached the highest value in the BVC unit (-8.4\%o). The end of this phase is marked by a sharp drop of $-0.9 \%$ in $\delta^{18} \mathrm{O}$ at $1173 \mathrm{~cm}$ depth. The ca 4950 varve year long period, from $1173 \mathrm{~cm}$ to $827 \mathrm{~cm}$, starts with a 780 varve year long period of lower values (mean: $-9.3 \%$ ), followed by a shift to higher values $(-8.4 \%)$. The further course of the curve is characterised by a general decrease of $\delta^{18} \mathrm{O}$ towards the BVC/MLP boundary with two superimposed prominent short-term lighter fluctuations. About 315 varve years before the upper limit of the BVC unit, a major fall in $\delta^{18} \mathrm{O}$ marks the beginning of the final decline, with lowest $\delta^{18} \mathrm{O}$ values directly before the prominent lithological shift at the BVC/MLP boundary. This shift to detrital-dominated sedimentation prevented the continuation of isotope analyses because endogenic calcite was 
not sufficiently available. The $\delta^{18} \mathrm{O}$ values of the varved interval $(\mathrm{C} 1)$ in the MLP unit are $1.1-1.2 \%$ higher than in the uppermost part of the BVC.
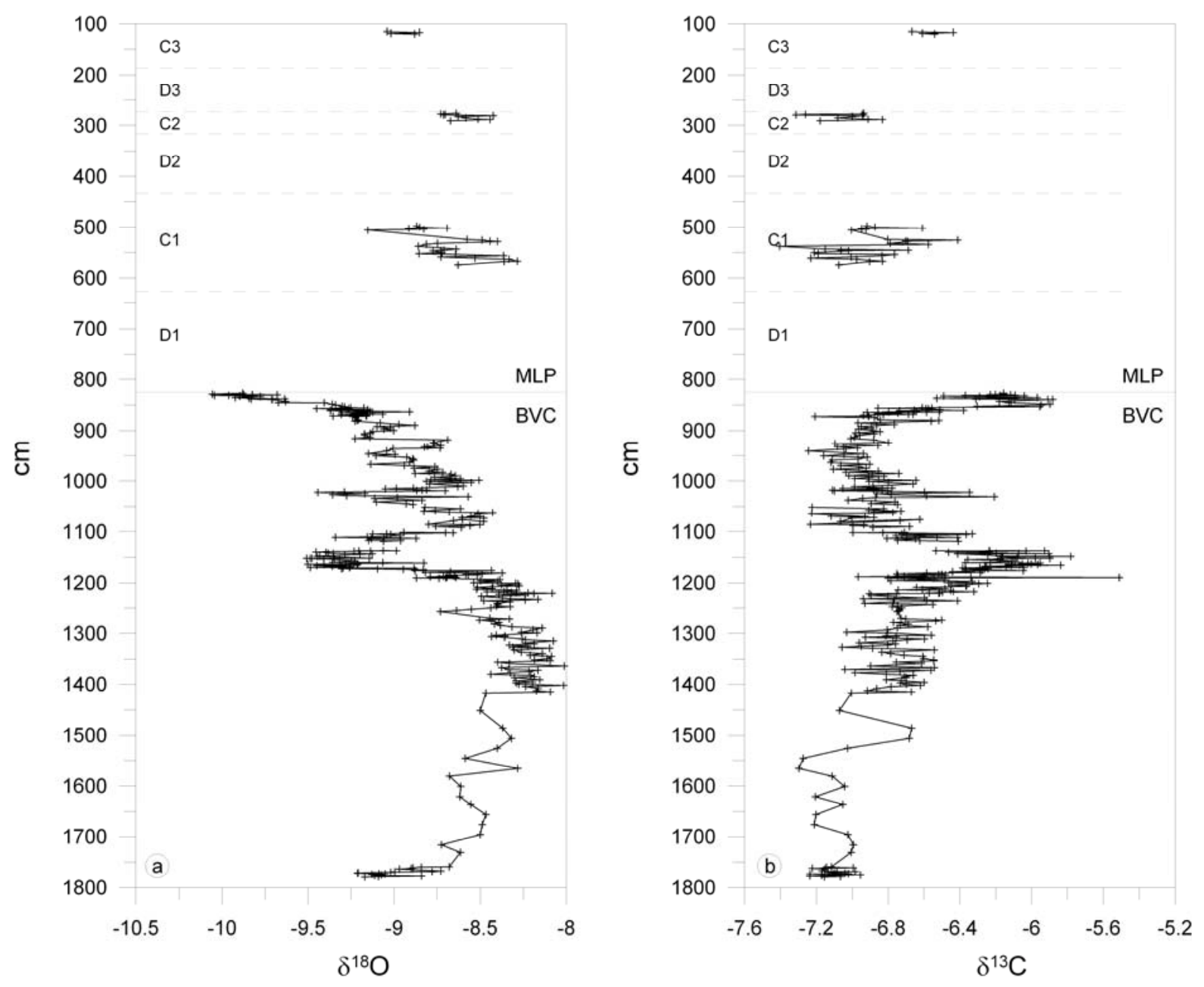

Fig. 5. $\delta^{18} \mathrm{O}$ (a) and $\delta^{13} \mathrm{C}(\mathrm{b})$ records for the BVC and MLP units. The ' 0 '-point of the depth scale is at the top of the studied sequence (see Fig. 3). $\mathrm{C} 1-\mathrm{C} 3$ are the endogenic calcite-dominated sediment intervals within the MLP unit. No isotope data are obtained for the intercalated D1-D3 intervals, which are dominated by detrital carbonated not allowing to sample pure endogenic calcite.

Particularly remarkable are the four prominent $\delta^{18} \mathrm{O}$ short-term oscillations (labelled as Pianico Isotope Oscillations, PIO; Fig. 6 and Table 2) within the BVC unit. The most prominent of these oscillations (PIO III) lasted 780 varve years, and was clearly longer than PIO I, II and IV, which spanned 165, 195 and 125 varve years, respectively (Table 2). The onset of PIO III is marked by a sudden drop in $\delta^{18} \mathrm{O}$ of $1.1 \%$ o to a mean value of $-9.3 \%$ o for this oscillation. From the three shorter oscillations, only PIO IV exhibits a $\delta^{18} \mathrm{O}$ decrease in about the same range $(-0.9 \%)$, whereas the amplitudes of PIO I and II are much smaller $(0.4-$ $0.5 \%$ ).

The $\delta^{13} \mathrm{C}$ values of the BVC unit range between $-5.5 \%$ and $-7.3 \%$ (Figs. $5 \mathrm{~b}$ and $6 \mathrm{~b}$; Table 1). The $\delta^{13} \mathrm{C}$ curve shows an increasing trend from the base of the BVC until the end of PIO III, 
when $\delta^{13} \mathrm{C}$ drops by about $0.9 \%$. During PIO III, $\delta^{13} \mathrm{C}$ reach a maximum of about $-5.8 \%$, thus exhibiting an oscillation inverse to the $\delta^{18} \mathrm{O}$ curve. Heavier $\delta^{13} \mathrm{C}$ oscillations were also recorded for PIO IV and the uppermost part of the BVC, where oxygen isotopes finally decline. In contrast, for PIO I, $\delta^{13} \mathrm{C}$ decreases parallel to the drop in $\delta^{18} \mathrm{O}$, while PIO II shows a complex behaviour, with first rising and then declining $\delta^{13} \mathrm{C}$ values.
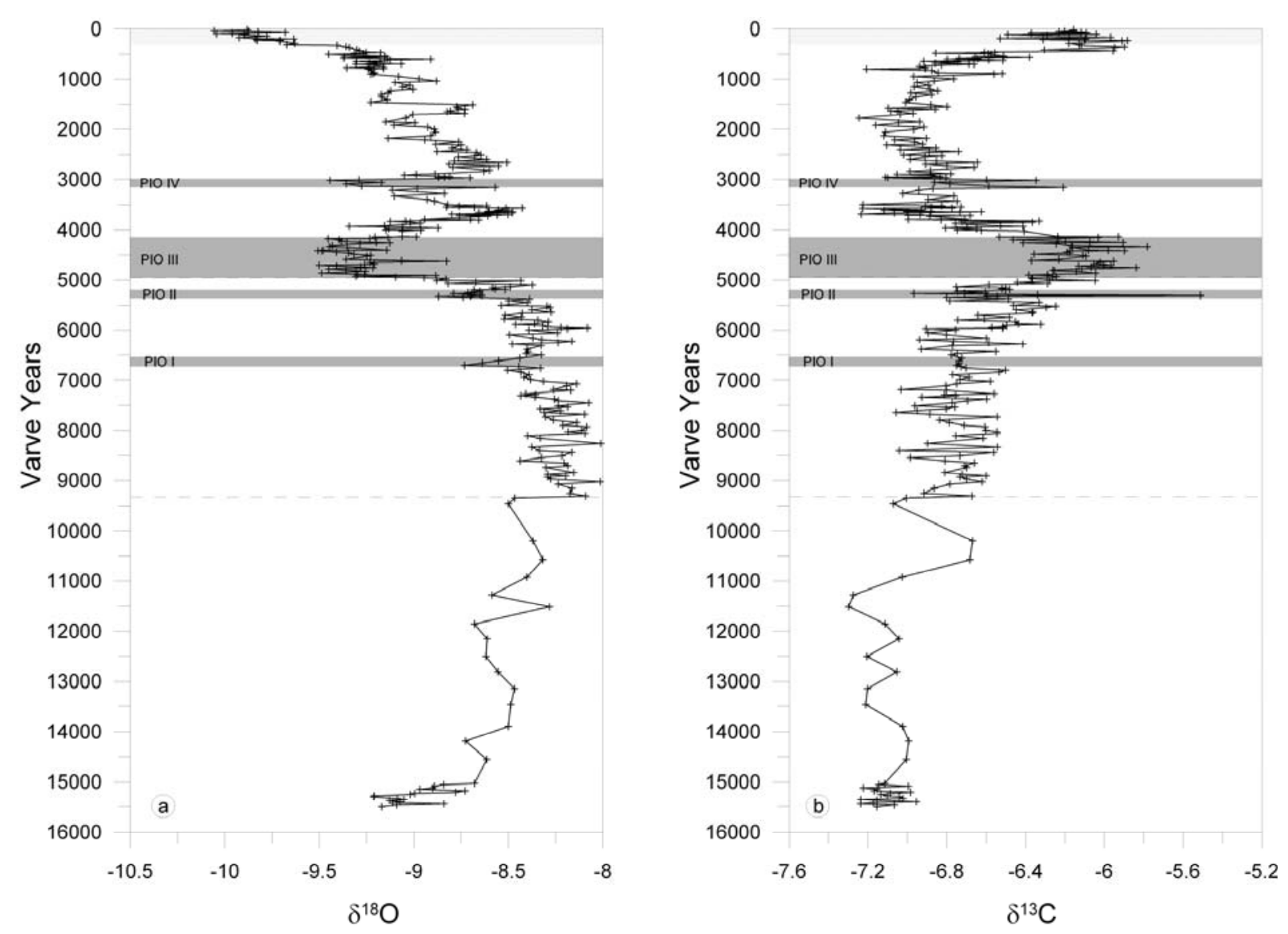

Fig. 6. $\delta^{18} \mathrm{O}$ and $\delta^{13} \mathrm{C}$ record for the peak interglacial (BVC unit) plotted against the floating varve chronology with the ' 0 ' year marking the end of the peak interglacial (= top of BVC unit). Dashed lines mark the three-partition of the isotope record as discussed in the text.

\begin{tabular}{cccccccc}
\hline zone & $\begin{array}{c}\text { number of } \\
\text { samples }\end{array}$ & \multicolumn{3}{c}{$\delta^{18} \mathrm{O}$} & & & $\delta^{13} \mathrm{C}$ \\
$\min$ & $\operatorname{mean}$ & $\max$ & $\min$ & mean \\
\hline & & & & & & & \\
MLP - C3 & 4 & -8.9 & -9.0 & -8.95 & -6.4 & -6.7 & -6.55 \\
MLP - C2 & 10 & -8.4 & -8.7 & -8.55 & -6.8 & -7.3 & -7.05 \\
MLP - C1 & 27 & -8.3 & -9.2 & -8.75 & -6.4 & -7.4 & -6.9 \\
BVC & 346 & -8.0 & -10.1 & -9.05 & -5.5 & -7.3 & -6.4 \\
& & & & & & & \\
\hline
\end{tabular}

Table $1 . \delta^{18} \mathrm{O}$ and $\delta^{13} \mathrm{C}$ maximum, minimum, mean values and overall amplitude of the isotope shifts for each carbonate interval in the MLP, for the whole BVC and for the three different parts recognisable in the $\delta^{18} \mathrm{O}$ of the BVC Unit.

Considering all samples, $\delta^{18} \mathrm{O}$ and $\delta^{13} \mathrm{C}$ exhibit a weak anticorrelation $(\mathrm{R}=-0.4 ; \mathrm{n}=346$; Fig. 7; Talbot, 1990). The $\delta^{18} \mathrm{O}$ and $\delta^{13} \mathrm{C}$ cross-plot (Fig. 7) reveals, however, that the isotope data form two populations (Fig. 7): a population with $\delta^{18} \mathrm{O}$ values included between ca $-9.25 \%$ and 
$-8 \%$ and $\delta^{13} \mathrm{C}$ values included between $-7.3 \%$ and $-6.2 \%$; a second population that presents $\delta^{18} \mathrm{O}$ values between ca $-9.25 \%$ and $-10.1 \%$ and $\delta^{13} \mathrm{C}$ values between $-6.6 \%$ and $-5.8 \%$. Taken separately, both the first $(\mathrm{R}=0.038 ; \mathrm{n}=286)$ and the second $(\mathrm{R}=0.066 ; \mathrm{n}=60)$ populations exhibit no correlation.

\begin{tabular}{|c|c|c|c|c|c|c|c|c|c|c|c|}
\hline \multirow[t]{2}{*}{ zone } & \multirow{2}{*}{$\begin{array}{l}\text { duration } \\
\text { (years) }\end{array}$} & \multirow{2}{*}{$\begin{array}{c}\text { number of } \\
\text { samples }\end{array}$} & \multicolumn{4}{|c|}{$\delta^{18} \mathrm{O}$} & \multicolumn{4}{|c|}{$\delta^{13} \mathrm{C}$} & \multirow{2}{*}{$\begin{array}{l}\text { correlation } \\
\text { coefficient }\end{array}$} \\
\hline & & & $\max$ & $\min$ & mean & drop & $\max$ & $\min$ & mean & drop & \\
\hline final drop & 467 & 26 & -9.2 & -10.1 & -9.65 & -0.9 & -5.9 & -6.6 & -6.25 & +0.7 & -0.03 \\
\hline PIO IV & 125 & 5 & -9.2 & -9.4 & -9.3 & -0.9 & -6.6 & -6.9 & -6.75 & +0.7 & -0.75 \\
\hline PIO III & 780 & 40 & -8.8 & -9.5 & -9.15 & -1.1 & -5.8 & -6.5 & -6.15 & +1.0 & -0.14 \\
\hline PIO II & 195 & 14 & -8.5 & -8.9 & -8.7 & -0.5 & -5.5 & -7.0 & -6.25 & +1.3 & +0.15 \\
\hline PIO I & 165 & 5 & -8.4 & -8.7 & -8.55 & -0.4 & -6.7 & -6.8 & -6.75 & -0.3 & +0.95 \\
\hline
\end{tabular}

Table 2. $\delta^{18} \mathrm{O}$ and $\delta^{13} \mathrm{C}$ maximum, minimum and mean values for the Piànico Isotopic Oscillations (PIO) and for the isotope decline at the end of the BVC unit The correlation coefficient between $\delta^{18} \mathrm{O}$ and $\delta^{13} \mathrm{C}$ for PIO IIV has been calculated for each fluctuation separately.

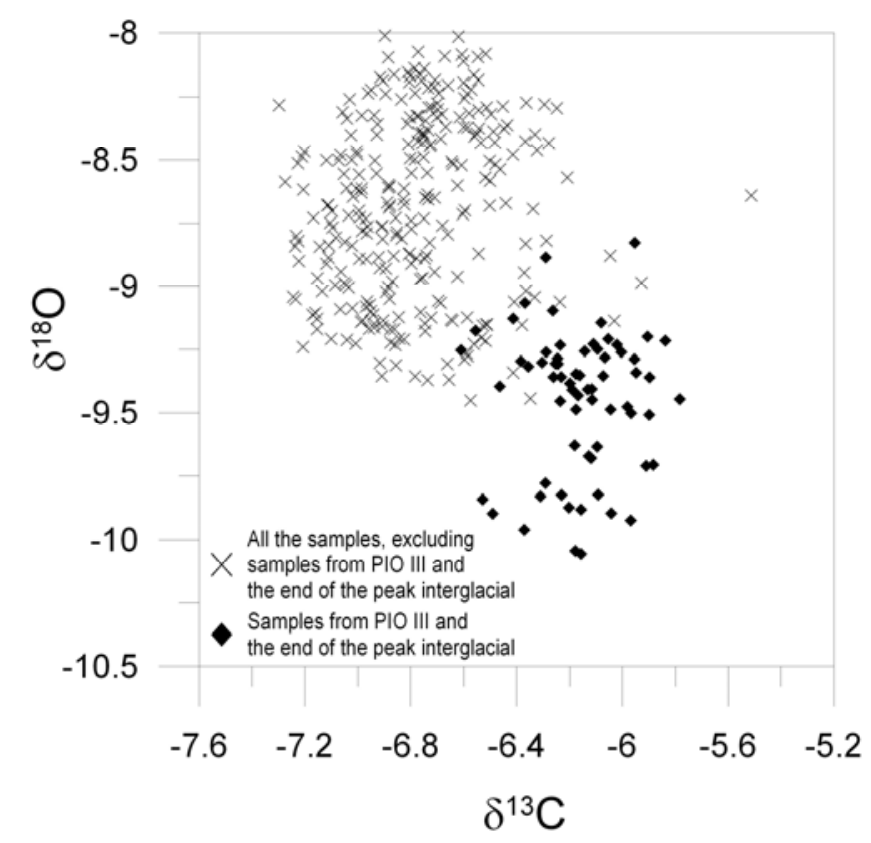

Fig. 7. Cross-plot between $\delta^{18} \mathrm{O}$ and $\delta^{13} \mathrm{C}$ exhibiting two populations: 286 samples from the peak interglacial, excluding PIO III and the end of peak interglacial (crosses), and the 60 samples from PIO III and the end of the peak interglacial (diamonds).

\section{Interpretation and discussion}

Palaeoclimatic interpretation from $\delta^{18} \mathrm{O}$ of lacustrine carbonates from palaeolakes is a particular challenge, because direct calibration with temperature or $\delta^{18} \mathrm{O}$ in precipitation $\left(\delta^{18} \mathrm{O}_{\text {precip }}\right)$ is hardly possible. Nevertheless, the comparison between the $\delta^{18} \mathrm{O}_{\text {carb }}$ record from Piànico with carbonate isotope records from other old interglacials, from Holocene and Lateglacial lake sediments (Table 3; Fig. 8) shows the degree of similarity between $\delta^{18} \mathrm{O}$ records from different sites and time periods, although it must be kept in mind that such 
geographic differences as, for example, location and relief are not considered. The general similarity of $\delta^{18} \mathrm{O}_{\text {carb }}$ from Piànico with many recent as well as palaeo lake records suggests, however, comparable processes of carbonate formation. Nevertheless, some distinct differences appear comparing the minimum $\delta^{18} \mathrm{O}$ values, commonly interpreted as indication of colder climate. All other $\delta^{18} \mathrm{O}$ records revealed lower minimum values than Piànico, except Ossówka in eastern Poland (Nitychoruk et al., 2005), the only other record corresponding to MIS 11. This might indicate a general difference between Holocene and MIS 11 climates, but regional isotope effects may also play a role. The $\delta^{18} \mathrm{O}_{\text {carb }}$ records from last interglacial lake sediments are more similar to those from Piànico and Ossówka than to Holocene records, except the minimum value of ca $-12 \%$ from the Mondsee record (Drescher-Schneider and Papesch, 1998). This light value, however, occurred during the penultimate deglaciation period and, thus, is not representative for interglacial conditions. Interestingly, the reason for the greatest difference of minimum $\delta^{18} \mathrm{O}_{\text {carb }}(>1 \%)$ between Holocene (Lake Greifen and Lake Gosciaz) and MIS 11-age lake sediments (Piànico and Ossówka) are data from the most recent sediments of the last century. Interpretation of these light $\delta^{18} \mathrm{O}_{\text {carb }}$ in very young sediments includes changes in air mass circulation (McKenzie and Hollander, 1993), but rules out changes in temperatures since global warming should have resulted in heavier $\delta^{18} \mathrm{O}_{\text {carb}}$. Other causes, such as non-equilibrium precipitation, could have also played a role (e.g. Fronval et al., 1995).

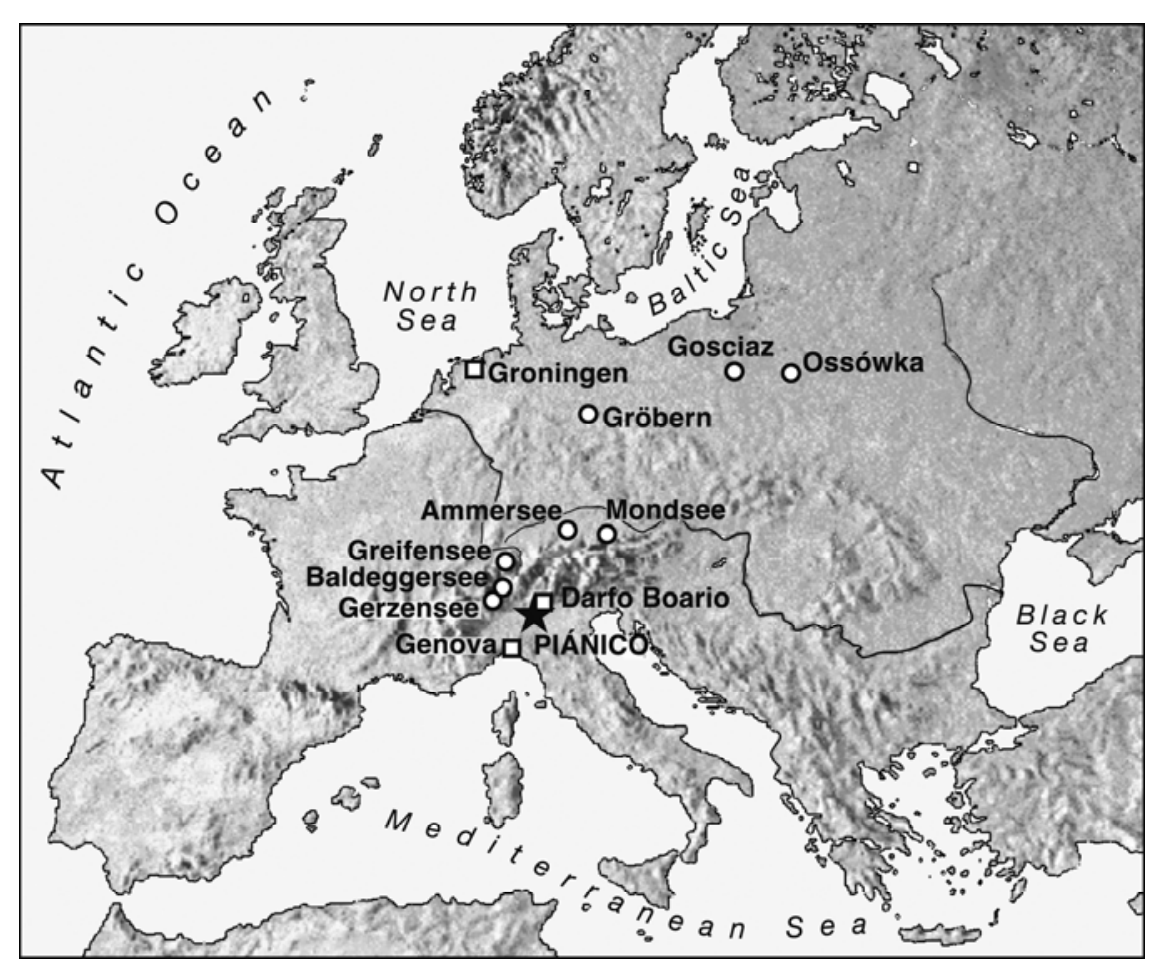

Fig. 8. Location of the $\delta^{18} \mathrm{O}$ carbonate records (circles) and of three measurement stations of $\delta^{18} \mathrm{O}$ data from modern precipitation (squares) as discussed in the text and in Table 3. 
Evaluation of the highest $\delta^{18} \mathrm{O}_{\text {carb }}$ values in the compared sediment sequences is additionally complicated because of a possible bias through contamination with detrital carbonate that, for most records, cannot be excluded (Mangili et al., in prep.). Detailed isotope analyses of endogenic calcite with varying amounts of detrital dolomite of marine Mesozoic origin in the Piànico record demonstrated a clear relation between the degree of contamination and the deviation towards higher $\delta^{18} \mathrm{O}$ values (Mangili et al., in prep.). For this study, only data from samples with detrital contamination $<4 \%$ are shown, so that a measurable bias through detrital material can be excluded. Presumably, this explains why the heaviest $\delta^{18} \mathrm{O}_{\text {carb }}$ from Piànico are lighter than in all compared records (Table 3), thus resulting in the narrowest amplitude of $\delta^{18} \mathrm{O}_{\text {carb }}$ (ca $2 \%$ ) for the Piànico record. Although unlikely, it can also not be fully excluded that this low amplitude of $\delta^{18} \mathrm{O}_{\text {carb }}$ variations is due to either a lower degree of climatic variability at Piànico, or a lower sensitivity of this lake system to climate variations.

\begin{tabular}{|c|c|c|c|c|c|c|c|}
\hline Site & $\begin{array}{c}\text { Elevation } \\
\text { (m a.s.l.) }\end{array}$ & Location & $\delta^{18} \mathrm{O} \max$ & $\delta^{18} \mathrm{O} \min$ & $\begin{array}{c}\delta^{18} \mathrm{O} \\
\text { amplitude }\end{array}$ & Time interval & $\begin{array}{l}\text { Lenght of the } \\
\text { record (years) }\end{array}$ \\
\hline & & & $(\%)$ & $(\%)$ & & & \\
\hline Pianico & 350 & $\begin{array}{l}45^{\circ} 48^{\prime} \mathrm{N} \\
10^{\circ} 02^{\prime} \mathrm{E}\end{array}$ & -8.01 & -10.06 & 2.05 & MIS 11 & 16000 \\
\hline Baldeggersee $^{1}$ & 423 & $\begin{array}{c}47^{\circ} 11^{\prime} \mathrm{N} 8^{\circ} \\
15^{\prime} \mathrm{E}\end{array}$ & -8 & -10.5 & 2.5 & $1885 \mathrm{AD}-1993 \mathrm{AD}$ & 108 \\
\hline Lake Greifen $^{2}$ & 435.3 & $\begin{array}{c}47^{\circ} 20^{\prime} \mathrm{N} \\
8^{\circ} 40^{\prime} \mathrm{E}\end{array}$ & -7.6 & -11.3 & 3.7 & $1750-1986$ & 236 \\
\hline Ammersee $^{3}$ & 520 & $\begin{array}{l}48^{\circ} 00^{\prime} \mathrm{N} \\
11^{\circ} 07^{\prime} \mathrm{E}\end{array}$ & $\sim-4.7^{\mathrm{a}}$ & $\sim-5.7^{\mathrm{a}}$ & $\sim 1$ & 8.2 ka event & 180 \\
\hline Gerzensee $^{4}$ & 600 & $\begin{array}{c}46^{\circ} 49^{\prime} \mathrm{N} \\
7^{\circ} 32^{\prime} \mathrm{E}\end{array}$ & -6.5 & -10.2 & 3.7 & Lateglacial & $\sim 6000$ \\
\hline Gerzensee $^{5}$ & 600 & $\begin{array}{c}46^{\circ} 49^{\prime} \mathrm{N} \\
7^{\circ} 32^{\prime} \mathrm{E}\end{array}$ & $\sim-5.9^{\mathrm{b}}$ & $\sim-10.0^{\mathrm{b}}$ & 4.1 & Lateglacial & 1850 \\
\hline Lake Gosciaz $^{6}$ & 64.3 & $\begin{array}{l}52^{\circ} 35^{\prime} \mathrm{N} \\
19^{\circ} 21^{\prime} \mathrm{E}\end{array}$ & -7.5 & -11 & 3.5 & $\sim 11.500$ to $1.200 \mathrm{cal} \mathrm{BP}$ & 10300 \\
\hline Lake Gosciaz $^{7}$ & 64.3 & $\begin{array}{l}52^{\circ} 35^{\prime} \mathrm{N} \\
19^{\circ} 21^{\prime} \mathrm{E}\end{array}$ & -7.5 & -10.5 & 3 & Lateglacial & $\sim 1700$ \\
\hline Gröbern $^{8}$ & $\sim 100$ & $\begin{array}{l}51^{\circ} 40^{\prime} \mathrm{N} \\
12^{\circ} 26^{\prime} \mathrm{E}\end{array}$ & $\sim-2$ & $\sim-10$ & $\sim 8$ & Eemian & - \\
\hline Mondsee $^{9}$ & 481 & $\begin{array}{l}47^{\circ} 48^{\prime} \mathrm{N} \\
13^{\circ} 23^{\prime} \mathrm{E}\end{array}$ & $\sim-7.8$ & $\sim-12$ & $\sim 4.2$ & Eemian & - \\
\hline Ossowka $^{10}$ & $\sim 150$ & $\begin{array}{l}52^{\circ} 06^{\prime} \mathrm{N} \\
23^{\circ} 08^{\prime} \mathrm{E}\end{array}$ & $\sim-3.8$ & $\sim-8.8$ & $\sim 5$ & MIS 11 & $\sim 35-39000$ \\
\hline $\begin{array}{c}\text { Ossowka }^{10} \\
\text { climatic optimum }\end{array}$ & $\sim 150$ & $\begin{array}{l}52^{\circ} 06^{\prime} \mathrm{N} \\
23^{\circ} 08^{\prime} \mathrm{E}\end{array}$ & -4.5 & -7 & 2.5 & MIS 11 & 16000 \\
\hline
\end{tabular}

Table 3. Compilation of different isotope records of lacustrine carbonates in Europe $\delta^{18} \mathrm{O}$ and $\delta^{13} \mathrm{C}$ maximum, minimum and the amplitude recorded in the different sequences are reported. Where $\delta^{18} \mathrm{O}$ values are not available from the original publications, they were graphically obtained from the figures and here reported as 'ca values ( )'. Data from (1) Teranes and McKenzie, 2001; (2) McKenzie and Hollander, 1993; (3) von Grafenstein et al., 1998; (4) Siegenthaler et al., 1984; (5) von Grafenstein et al., 2000; (6) Różański et al., 1998; (7) Kuc et al., 1998; (8) Boettger et al., 2000; (9) Drescher-Schneider and Papesch, 1998; (10) Nitychoruk et al., 2005. 


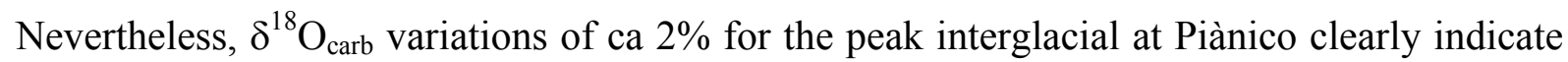
the presence of climate change. In particular, the four light oscillations in $\delta^{18} \mathrm{O}_{\text {carb }}$ (PIO I-IV), as well as the decline at the end of peak interglacial conditions, indicate pronounced shortterm climatic changes within a period of 10,000 years of generally relative stable interglacial climate conditions (Fig. 6). Since isotope fractionation during calcite precipitation in the epilimnion is inversely dependent on water temperature $\left(-0.23 \% /{ }^{\circ} \mathrm{C}\right.$; Epstein et al., 1953$)$, a lowering in $\delta^{18} \mathrm{O}_{\text {carb }}$ should be expected to reflect warmer water in the epilimnion. However, comparable lowerings in $\delta^{18} \mathrm{O}_{\text {carb }}$ from Holocene and Lateglacial lake records are commonly interpreted as indications for climatic cooling (Siegenthaler and Eicher, 1986; Kuc et al., 1998; von Grafenstein et al., 1998) because of the superimposed effect of $\delta^{18} \mathrm{O}_{\text {precip }}$ which, in turn, is mainly controlled by air temperature. The relationship between $\delta^{18} \mathrm{O}_{\text {precip }}$ and mean annual air temperature, known as the Dansgaard relationship, amounts to $+0.6 \% /{ }^{\circ} \mathrm{C}$ at mid and high latitudes (Dansgaard, 1964; Różański et al., 1992, 1993). Subtracting the fractionation effect of calcite formation $\left(-0.23 \% /{ }^{\circ} \mathrm{C}\right)$ from this value results in a relation between air temperature and lake $\delta^{18} \mathrm{O}_{\text {carb }}$ of ca $0.37 \% /{ }^{\circ} \mathrm{C}$ for open lakes (Leng and Marshall, 2004). Applying the same factor to the Piànico record, the strongest shifts of $-1.1 \%$ for PIO III and $-0.7 \%$ at the end of the peak interglacial suggest temperature decreases of ca $3^{\circ} \mathrm{C}$ and $1.9^{\circ} \mathrm{C}$.

These values are regarded as maximum estimates, because additional factors as (1) seasonal effects, (2) changes in atmospheric circulation and (3) variations of the moisture source might have contributed to the drops in $\delta^{18} \mathrm{O}_{\text {carb. }}$ (1) A shift of the dominant amount of annual rainfall into the winter season could have also shifted oxygen isotopic compositions to lowest values. (2) Precipitation at Piànico can originate from either Atlantic or Mediterranean sources. The averages of the mean monthly $\delta^{18} \mathrm{O}_{\text {precip }}$ in Genoa (Mediterranean source) and Groningen (Atlantic source) differ by 2.6\% for the decade 1985-1995 (data from IAEA/WMO, 2004). Therefore, a shift caused, for example, by more frequent invasions of Atlantic air masses would have resulted in changes of isotope composition of precipitation towards lower values. (3) In addition, sea surface temperatures in the moisture source region might have also contributed to the observed lowerings of $\delta^{18} \mathrm{O}$. Most of the present day precipitation in the Southern Alps originates from Mediterranean low pressure systems generated over the Gulf of Genoa (H.M.S.O., 1962) through southerly flows of warm and moist Mediterranean air into northern Italy (e.g. Brunetti et al., 2000). Thus, a lowering of SST in the Gulf of Genoa could

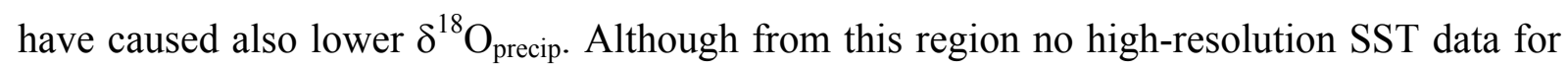


MIS 11 have been published, data from the Iberian Margin indicate a SST decrease of ca $2.3^{\circ}$ $\mathrm{C}$ during the warmest part of the MIS 11 interglacial (de Abreu et al., 2005).

The most striking oscillation is PIO III, mainly because of its long duration of 780 years. This cooling occurred after more than 10,000 varve years of warm interglacial conditions, and is even seen in a sudden change in vegetation from broad-leaved to conifer dominated taxa (Rossi, 2003). Compared to well-known Holocene cold climatic oscillations, which lasted no longer than 2-3 centuries, the duration of PIO III is exceptional. In contrast, the amplitude of $1.1 \%$ compares well with that of $1 \%$ reported for the so-called $8.2 \mathrm{ka}$ event in the Holocene (von Grafenstein et al., 1998) that, however, was significantly shorter (180-200 years; Prasad et al., 2006). Longer lasting cold phases like the Younger Dryas are only reported from the Lateglacial, but this period was characterised by a much more pronounced light oxygen isotope swing (Kuc et al., 1998). Discussing the triggering mechanisms for PIO III is difficult and requires additional high-resolution data from marine cores, in order to better understand changes in thermohaline circulation during this period. Nevertheless, it can be assumed that the potential triggers for Holocene climate deterioration, i.e. changes in thermohaline circulation and solar radiation (Bond et al., 1997, 2001), are the most likely candidates for also explaining PIO III. This would imply, however, that either the sun had a longer weak period during MIS 11 than experienced during the Holocene so far, or that longer and/or stronger inflow of freshwater into the North Atlantic had lastingly changed the thermohaline circulation. Potential sources for freshwater can be either enhanced circum-Atlantic river runoff or glacial meltwater from Greenland.

The changes in $\delta^{13} \mathrm{C}_{\text {carb }}$ during the four cold oscillations are difficult to interpret because they are not always in the same direction. A likely explanation for the larger shifts of $\delta^{13} \mathrm{C}_{\text {carb }}$ during PIO II-IV and the final decline in $\delta^{18} \mathrm{O}_{\text {carb }}$ during the end of the peak interglacial is a change in isotopic composition of water inflow (McKenzie, 1985; Leng and Marshall, 2004). Since $\delta^{13} \mathrm{C}_{\text {carb }}$ values correspond to the isotopic composition of dissolved inorganic carbon (DIC) in the lake water body (McKenzie, 1985), heavier $\delta^{13} \mathrm{C}_{\mathrm{DIC}}$ due to increased dissolution of carbonates with higher $\delta^{13} \mathrm{C}$ values in the catchment (mean $\delta^{13} \mathrm{C}$ values of the measured dolomite: $+0.3 \%$; Mangili et al., in prep.) might be the cause for these changes.

The anticorrelation between $\delta^{18} \mathrm{O}$ and $\delta^{13} \mathrm{C}$ excludes enhanced evaporation as a cause of higher $\delta^{13} \mathrm{C}$ values. A link of $\delta^{13} \mathrm{C}$ to regional vegetation changes is also unlikely, since the latter occurred after the isotope shift. The anticorrelation observed between $\delta^{18} \mathrm{O}$ and $\delta^{13} \mathrm{C}$ is caused by the presence of different isotope populations. In the $\delta^{18} \mathrm{O}$ and $\delta^{13} \mathrm{C}$ cross-plot (Fig. 7), the distinction of two populations is due to the $\delta^{18} \mathrm{O}$ drop and $\delta^{13} \mathrm{C}$ rise at the 1000 year 
cold period, and the climate deterioration at the end of the peak interglacial (Fig. 7b). This contemporaneous change in isotope ratios is probably due to a lowering of lake water temperature and/or changes in atmospheric circulation or at the moisture source, and increased dissolution of carbonates with high $\delta^{13} \mathrm{C}$ values in the catchment.

\subsection{Comparison with other 400 ka old records}

On the basis of the tephrochronological match of the distal volcanic ash layer with the Roccamonfina Brown Leucitic Tuff (BLT; Brauer et al., 2007b), the stratigraphic position of the Piànico interglacial is assumed to correspond to MIS 11. This calls for a tentative correlation with marine and ice records from this time interval (Fig. 9). Although a precise correlation is not possible due to the rather large dating errors of the BLT (Giannetti, 2001), it appears likely that the $15.5 \mathrm{ka}$ long interglacial sequence from Piànico correlates with the ca $18 \mathrm{ka}$ 'full interglacial' period during MIS 11, as defined by de Abreu et al. (2005) in the marine core MD01-2443 from the Iberian Margin. Taking into consideration a major hiatus at the base of the Piànico interglacial through a major slump deposit, which include reworked varved intervals (Brauer et al., 2007a), the length of the period of interglacial warmth, as indicated by the continuous formation of calcite varves, is in good agreement with the peak interglacial in core MD01-2443. Interestingly, the length of the 'climatic optimum' reported from the Ossówka site in Poland is about the same (16 ka; Nitychoruk et al., 2005), also suggesting a correlation with the peak interglacial at Piànico. Accepting this correlation led us to further speculate on possible links even of more detailed features of these proxy records. During the full interglacial period in core MD01-2443, a drop in SSTs of ca $2.3^{\circ} \mathrm{C}$ is recorded (de Abreu et al., 2005), which might reflect the same climatic fluctuation as in PIO III (Fig. 9), and a ca $1 \%$ drop in $\delta^{18} \mathrm{O}_{\text {carb }}$ is observed in the Ossówka record at ca $37 \mathrm{~m}$ depth (Nitychoruk et al., 2005). As mentioned before, these correlations are speculative, in particular because marine records from the North Atlantic (Oppo et al., 1998; McManus et al., 1999) and the Antarctic ice core (EPICA community members, 2004) do not show such shortterm intra-interglacial climate oscillations (Fig. 9). Possible explanations for these differences include regional climate differences, sensitivity of proxies and, last but not least, time resolution of the data series. Despite the present uncertainties of correlation, the clear indication of a centennial-scale interglacial climate oscillation at Piànico calls for further high-resolution studies and efforts to improve the dating precision. 


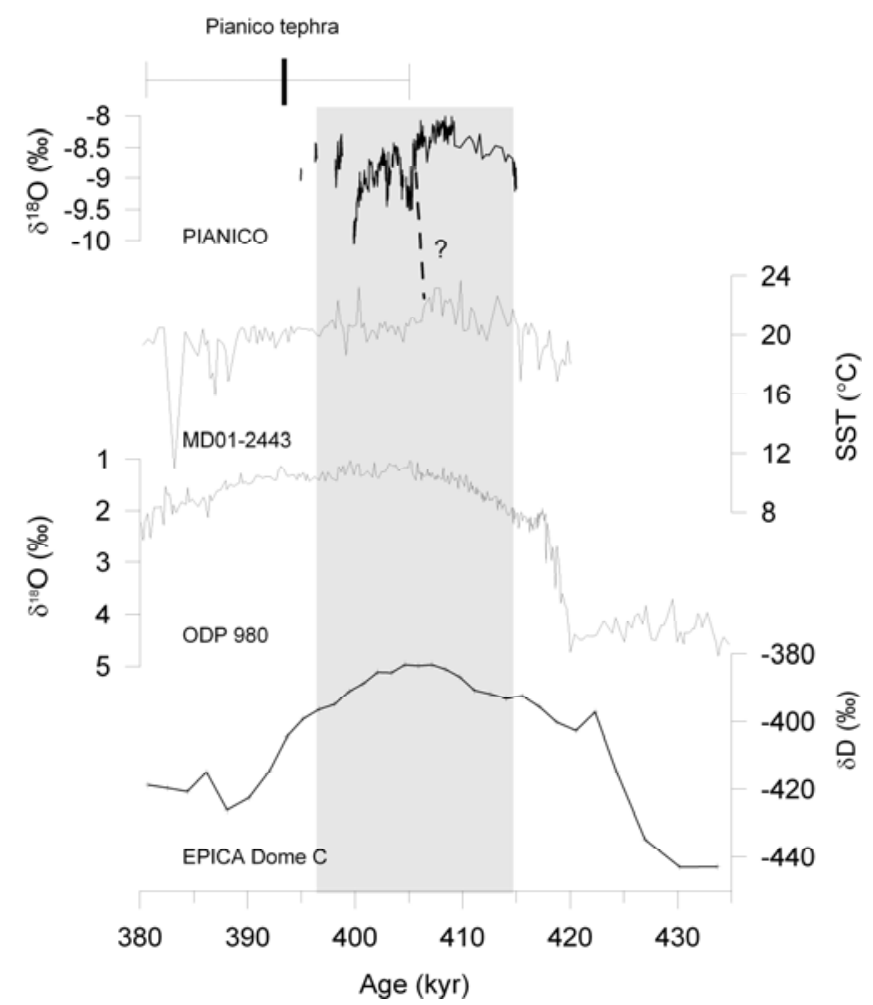

Fig. 9. Comparison of the $\delta^{18} \mathrm{O}$ record from Piànico interglacial with the SST record of MD01-2443, the $\delta^{18} \mathrm{O}$ record of Neogloboquadrina pachiderma dextralcoiling from ODP site 980 (McManus et al., 1999 ) and the $\delta$ D EPICA record (EPICA community members, 2004). The $18 \mathrm{ka}$ long 'full interglacial' period as defined by de Abreu et al. (2005) is indicated by the grey bar. The dashed line indicates possible correlation of PIO III with a drop in the SST record. The position of the distal deposit of the Roccamonfina Brown Leucitic Tuff is indicated as 'Piànico Tephra' with error bars of the dated near-vent deposits $(393 \pm 12 \mathrm{ka}$; Giannetti, 2001).

\section{Conclusions}

The $\delta^{18} \mathrm{O}$ record from the Piànico sediments represents a 15,500 year series of natural interglacial climate variability. The varved nature of the sediments allows sub-sampling in well-defined and precise five year intervals, and provides information about short-term climatic fluctuations at decadal resolution. Four lighter $\delta^{18} \mathrm{O}_{\text {carb }}$ fluctuations reflect rapid climate shifts during peak interglacial conditions about $400 \mathrm{ka}$ ago. Most of these oscillations are comparable in amplitude and duration with Holocene climate changes, except the most prominent period of climatic deterioration, which occurred after 10,000 years of relative climatic stability and lasted for 780 varve years, thus much longer than known Holocene cold periods. This cold period is expressed by a drop of $1.1 \%$ in $\delta^{18} \mathrm{O}_{\text {carb }}$ and a rapid change in vegetation, and might be linked to a drop in SSTs recorded at the Iberian margin. Three shorter cold oscillations with durations between 125 and 195 varve years have smaller $\delta^{18} \mathrm{O}$ amplitudes. Another $0.7 \%$ decline of $\delta^{18} \mathrm{O}_{\text {carb }}$ occurred 315 varve years before the end of peak interglacial conditions, which is also marked by a distinct change from an autochthonous to an allochthonous sedimentation regime. Most striking, however, is the long period of climate deterioration reflected by PIO III that exceeds Holocene cold phases, thus suggesting that the present interglacial has not yet experienced the full range of potential natural interglacial 
climate variability. Therefore, a better knowledge of the triggering mechanism for this oscillation is crucial for evaluating possible future changes.

\section{Acknowledgements}

We wish to thank G. Arnold, D. Berger and M. Köhler for preparing high-quality thin sections. M. Dziggel and A. Hendrich helped with the lay out of the figures.

We are grateful to Lucia de Abreu for providing the data from core MD01-2443 used in Fig. 9. Data of isotopic composition of recent precipitation are from the IAEA/ WMO database. We acknowledge the Centre for Isotope Research, Groningen, The Netherlands and the Istituto Internazionale per le Ricerche Geotermiche, Pisa, Italy.

The comments of Michael Talbot and of an anonymous reviewer improved an earlier version of this manuscript.

\section{References}

Amsler, M., 1900. Flore interglaciaire de Pianico. Compte Rendu des travaux de la Soc. Helvetique de Sc. nat. reunie a Thusis, 44-46.

Berger, A., Loutre, M.F., 2002. An exceptionally long interglacial ahead? Science 297, 12871288 .

Binka, K., Nitychoruk, J., 1995. Mazovian (Holsteinian) lake sediments at Woskrzenice near Biala Podlaska. Geological Quarterly 39 (1), 109-120.

Boettger, T., Junge, F.W., Litt, T., 2000. Stable climatic conditions in central Germany during the Last Interglacial. Journal of Quaternary Science 15 (5), 469-473.

Bond, G., Showers, W., Cheseby, M., Lotti, R., Almasi, P., deMenocal, P., Priore, P., Cullen, H., Hadjas, I., Bonani, G., 1997. A pervasive millennial-scale cycle in North Atlantic Holocene and glacial climates. Science 278, 1257-1266. 
Bond, G., Kromer, B., Beer, J., Muscheler, R., Evans, M.N., Showers, W., Hoffmann, S., Lotti-Bond, R., Hajdas, I., Bonani, G., 2001. Persistent solar influence on North Atlantic climate during the Holocene. Science 294, 2130-2136.

Brauer, A., Mangili, C., Moscariello, A., 2007a. Palaeoclimatic implications from microfacies data of a 5900 varve time series from the Pianico interglacial sediment record, Southern Alps. Palaeogeography, Palaeoclimatology, Palaeoecology, accepted for publication.

Brauer, A., Wulf, S., Mangili, C., Moscariello, A., 2007b. Tephrochronological dating of varved interglacial lake deposits from Piànico-Sèllere (Southern Alps, Italy) to around $400 \mathrm{ka}$. Journal of Quaternary Science 22 (1), 85-96.

Brunetti, M., Buffoni, L., Maugeri, M., Nanni, T., 2000. Precipitation intensity trends in Northern Italy. International Journal of Climatology 20, 1017-1031.

Casati, P., 1968. Alcune osservazioni sul bacino lacustre pleistocenico di Pianico (Lombardia). Geologia-Istituto Lombardo (Rend. Sc.) A 102, 575-595.

Dansgaard, W., 1964. Stable isotopes in precipitation. Tellus XVI (4), 436-468.

de Abreu, L., Abrantes, F., Shackleton, N.J., Tzedakis, P.C., McManus, J.F., Oppo, D.W., Hall, M.A., 2005. Ocean climate variability in the eastern North Atlantic during interglacial Marine Isotope Stage 11: a partial analogue to the Holocene? Paleoceanography 20.

Drescher-Schneider, R., Papesch, W., 1998. A contribution towards the reconstruction of Eemian vegetation and climate in central Europe: first results of pollen and oxygen-isotope investigations from Mondsee, Austria. Vegetation History Archaeobotany 7, 235-240.

EPICA community members, 2004. Eight glacial cycles from an Antarctic ice core. Nature 429, 623-628.

Epstein, S., Buchsbaum, R., Lowenstam, H.A., Urey, H.C., 1953. Revised carbonate-water isotopic temperature scale. Bulletin of the Geological Society of America 64, 1315-1326. 
Fronval, T., Jensen, N.B., Buchardt, B., 1995. Oxygen isotope disequilibrium precipitation of calcite in Lake Arresø, Denmark. Geology 23, 463-466.

Giannetti, B., 2001. Origin of the calderas and evolution of Roccamonfina volcano. Journal of Volcanology and Geothermal Research 106, 301-319.

Hilfinger IV, M.F., Mullins, H.T., Burnett, A., Kirby, M.E., 2001. A 2500 year sediment record from Fayetteville Green Lake, New York: evidence for anthropogenic impacts and historic isotope shift. Journal of Paleolimnology 26, 293-305.

H.M.S.O. (Her Majesty's Stationery Office), 1962. Weather in the Mediterranean. Her Majesty's Stationery Office, London.

IAEA/WMO, 2004. Global Network of Isotopes in Precipitation. The GNIP Database. Accessible at: $<$ http://isohis.iaea.org $>$

Kirby, M.E., Patterson, W.P., Mullins, H.T., Burnett, A.W., 2002. Post- Younger Dryas climate interval linked to circumpolar vortex variability: isotopic evidence from Fayetteville Green Lake, New York. Climate Dynamics 19, 321-330.

Kuc, T., Różański, K., Duliński, M., 1998. Isotopic indicators of the Late-Glacial/Holocene transition recorded in the sediments of Lake Gościąż. In: Ralska-Jasiewiczowa, M., Goslar, T., Madeyska, T., Starkel, L. (Eds.), Lake Gościąż, Central Poland A Monographic study Part 1. W. Szafer Instiute of Botany and Polish Academy of Sciences, Krakow, pp. 158-162.

Leng, M.J., Marshall, J.D., 2004. Palaeoclimate interpretation of stable isotopes data from lake sediment archives. Quaternary Science Reviews 23, 811-831.

Leng, M.J., Roberts, N., Reed, J.M., Sloane, H.J., 1999. Late Quaternary palaeohydrology of the Konya Basin, Turkey, based on isotope studies of modern hydrology and lacustrine carbonates. Journal of Paleolimnology 22, 187-204.

Loutre, M.F., 2003. Clues from MIS 11 to predict the future climate-a modelling point of view. Earth and Planetary Science Letters 212, 213-224. 
Maffei, L., 1924. Contributo allo studio della flora fossile del deposito lacustre di Pianico. Atti Istituto Botanico Universitá di Pavia III, 47-69.

Mangili, C., Brauer, A., Moscariello, A., Naumann, R., 2005. Microfacies of detrital event layers deposited in Quaternary varved lake sediments of the Piànico-Sèllere Basin (northern Italy). Sedimentology 52, 927-943.

Mangili, C., Brauer, A., Plessen, B., Moscariello, A., in prep. Effects of detrital carbonate on the interpretation of stable oxygen and carbon isotopes from the interglacial lake record of Piànico.

McKenzie, J.A., 1985. Carbon isotopes and productivity in the lacustrine and marine environment. In: Stumm, W. (Ed.), Chemical Processes in Lakes. Wiley, New York, pp. 99118.

McKenzie, J.A., Hollander, D.J., 1993. Oxygen-Isotope Record in Recent Carbonate Sediments from Lake Greifen, Switzerland (1750-1986): application of continental isotopic indicator for evaluation of changes in climate and atmospheric circulation patterns. In: Swart, P.K., Lohmann, K.C., McKenzie, J., Savin, S. (Eds.), Climate Change in Isotopic Records, vol. 78. Geophysical Monograph, American Geophysical Union, pp. 101-111.

McManus, J.F., Oppo, D.W., Cullen, J.L., 1999. A 0.5-millon-year record of millennial-scale climate variability in the North Atlantic. Science 283, 971-975.

Moscariello, A., Ravazzi, C., Brauer, A., Mangili, C., Chiesa, S., Rossi, S., de Beaulieu, J.-L., Reille, M., 2000. A long lacustrine record from the Pianico-Sellere Basin (Middle-Late Pleistocene, Nothern Italy). Quaternary International 73/74, 47-68.

Nitychoruk, J., 2000. Climate reconstruction from stable-isotope composition of the Mazovian Interglacial (Holsteinian) lake sediments in eastern Poland. Acta Geologica Polonica 50 (2), 247-294. 
Nitychoruk, J., Binka, K., Hoefs, J., Ruppert, H., Schneider, J., 2005. Climate reconstruction for the Holsteinian Interglacial in eastern Poland and its comparison with isotopic data from Marine Isotope Stage 11. Quaternary Science Reviews 24, 631-644.

Oppo, D.W., McManus, J.F., Cullen, J.L., 1998. Abrupt climates events 500,000 to 340,000 years ago: evidence from Subpolar North Atlantic sediments. Science 279, 1335-1338.

Petit, J.-R., Jouzel, J., Raynaud, D., Barkov, N.I., Barnola, J.-M., Basile, I., Bender, M., Chappellaz, J., Davis, M., Delaygue, G., Delmotte, M., Kotlyakov, V.M., Legrand, M., Lipenkov, V.Y., Lorius, C., Pepin, L., Ritz, C., Saltzman, E., Stievenard, M., 1999. Climate and atmospheric history of the past 420,000 years from the Vostok ice core, Antarctica. Nature 399, 429-436.

Prasad, S., Brauer, A., Rein, B., Negendank, J.F.W., 2006. Rapid climate change during the early Holocene in western Europe and Greenland. The Holocene 16, 153-158.

Provincia di Bergamo, 2000. Carta Geologica della Provincia di Bergamo. Note illustrative. Provincia di Bergamo, Bergamo.

Rossi, S., 2003. Etude pollinique de la sequence lacustre Pleistocene de Piànico-Sèllere (Italie). Ph.D. Thesis, Université de Droit, d'Economie et des Sciences d'Aix Marseille III.

Różański, K., Araguäs-Araguäs, L., Gonfiantini, R., 1992. Relation between long-term trends of oxygen-18 isotope composition of precipitation and climate. Science 258, 981-985.

Różański, K., Araguäs-Araguäs, L., Gonfiantini, R., 1993. Isotopic patterns in modern global precipitation. In: Swart, P.K., Lohmann, K.C., McKenzie, J., Savin, S. (Eds.), Climate Change in Continental Isotopic Records (Geophysical Monograph), vol. 78.

Różański, K., Kuc, T., Duliński, M., Wachniew, P., 1998. Oxygen and carbon isotope composition of authigenic carbonates in the Holocene part of the lake Gościąż sediments. In: Ralska-Jasiewiczowa, M., Goslar, T., Madeyska, T., Starkel, L. (Eds.), Lake Gościąż, Central Poland A Monographic Study Part 1. W. Szafer Instiute of Botany and Polish Academy of Sciences, Krakow, pp. 229-232. 
Schwander, J., Eicher, U., Ammann, B., 2000. Oxygen isotopes of lake marl at Gerzensee and Leysin (Switzerland), covering the Younger Dryas and two minor oscillations, and their correlation to the GRIP ice core. Palaeogeography, Palaeoclimatology, Palaeoecology 159, 203-214.

Siegenthaler, U., Eicher, U., Oeschger, H., Dansgaard, W., 1984. Lake sediments as continental $\delta^{18} \mathrm{O}$ records from the glacial/post-glacial transition. Annals of Glaciology 5, 149152.

Siegenthaler, U., Eicher, U., 1986. Stable oxygen and carbon isotope analyses. In: Berglund, B.E. (Ed.), Handbook of Holocene Palaeoecology and Palaeohydrology. Wiley, New York, pp. $407-422$.

Spötl, C., Vennemann, T.W., 2003. Continuous-flow isotope ratio mass spectrometric analysis of carbonate minerals. Rapid Communications in Mass Spectrometry 17, 1004-1006.

Talbot, M.R., 1990. A review of the palaeohydrological interpretation of carbon and oxygen isotopic ratios in primary lacustrine carbonates. Chemical Geology (Isotope Geoscience Section) $80,261-279$.

Teranes, J.L., McKenzie, J.A., 2001. Lacustrine oxygen isotope record of 20th-century climate change in central Europe: evaluation of climatic controls on oxygen isotopes in precipitation. Journal of Paleolimnology 26, 131-146.

von Grafenstein, U., Erlenkeuser, H., Müller, J., Jouzel, J., Johnsen, S., 1998. The cold event 8200 years ago documented in oxygen isotope records of precipitation in Europe and Greenland. Climate Dynamics 14, 73-81.

von Grafenstein, U., Eicher, U., Erlenkeuser, H., Ruch, P., Schwander, J., Ammann, B., 2000. Isotope signature of the Younger Dryas and two minor oscillations at Gerzensee (Switzerland): palaeoclimatic and palaeolimnologic interpretation based on bulk and biogenic carbonates. Palaeogeography, Palaeoclimatology, Palaeoecology 159, 215-229. 